Research Article

www.ijrap.net

\title{
A STUDY ON THE EFFICACY OF SIDHARTHAKADI YOGA IN THE MANAGEMENT OF MANIA WITHOUT PSYCHOTIC SYMPTOMS-AN UNCONTROLLED CLINICAL TRIAL
}

T.S. Manikandan*, M. Jithesh

Dept. of Kayachikitsa, V.P.S.V. Ayurveda College, Kottakkal, Malappuram (Dist), Kerala, India

Received on: 17/08/12 Revised on: 19/10/12 Accepted on: 01/11/12

\author{
*Corresponding author \\ E-mail: drtsmanikandan@gmail.com \\ DOI: 10.7897/2277-4343.03637 \\ Published by Moksha Publishing House. Website www.mokshaph.com \\ All rights reserved.
}

\section{ABSTRACT}

Psychiatry in Ayurveda is called Bhootavidya. All mental disorders come under bhootavidya. Various types of treatment modalities are described in Ayurvedic classics for mental disorders. They include spiritual healing, psychotherapy and pharmacotherapy. Ayurvedic treatment is based on balancing of humors of body and mind. So, adverse effects are comparatively less.

But, only a few of the formulations and treatment modalities are in practice today. There is much to be studied on. One among them is Sidharthakadi Yoga. The indication is in graha especially Asuragraha. Asuragraha has features like anger, hyperactivity, grandiosity and overconfidence. One of the disorders similar to this in modern psychiatry is mania. It is based on this view point, the present study was conducted. Sidharthakadi Yoga is prepared in two forms-as gutika for nasya and as tablet for intake. The study was conducted on 20 subjects. Nasya with Sidharthakadi Gutika was done for 7 days and tablets were given for intake for 30 days ( 3 tabs twice daily) after the course of nasya. Assessment was done before nasya, after 7 days of nasya and after 30 days of tablet intake. The assessment was done with Young Mania Rating Scale. It was observed that Sidharthakadi Yoga has significant effect in the management of mania without psychotic symptoms.

Keywords: Sidharthakadi Yoga, Nasya, Mania without psychotic symptoms

\section{INTRODUCTION}

Depression and mania are the abnormally lowered or raised states of mood. Mania is a dangerous situation. It affects the social and occupational life very badly. The affected person may do crimes like homicide, rape etc and there is a risk of suicide also. They will be harmful to the society and to themselves. There is chance for careless driving leading to accidents. There is chance for spending of money without a limit and this may cause financial loss. Family life will be broken due to lack of patience and understanding. There is also a chance for frequent quarrels finally leading to divorce. The relatives and friends also will have to suffer the consequences of the activities of the patients.

In Ayurveda also, there are descriptions about violent and hyperactive conditions similar to mania and their management is described. For example- Paittika unmada ${ }^{1}$, Vatika unmada ${ }^{2}$, Rakshasagraha ${ }^{3}$, Brahmarakshasa graha ${ }^{4}$ etc. But there is need of research for their clinical efficacy in conditions like mania. For example, Sidharthakadi Agada ${ }^{5}$, mentioned in Bhootapratișhedha chapter in Ashtangahrudaya Uttarasthana is indicated in all grahas especially Asuragrahas. The symptoms of Asuragraha are having some similarities to mania e.g. grandiose ideas, irritability, overconfidence etc. so, the clinical efficacy of Siddhartakadi Yoga in Mania is selected for this study.

Only one research has been reported on mania in Ayurveda. It was by C. Sudhakar et al (2006) V.P.S.V Ayurveda College Kottakkal, "A clinical study on Bipolar Disorder and its management with Darvigutika Anjana with special reference to Mania without psychotic symptoms"

No studies are reported on Sidharthakadi yoga.

\section{Aims and objectives}

To study the efficacy of Siddhartakadi Yoga in the management of Mania without psychotic symptoms.

\section{MATERIALS}

- Concerned literature

- Participants 20 in number

- Siddhartakadi tablets

- Siddhartakadi Gutika (for Nasya)

- Consent Form

- Case Record Form (CRF)

Clinical Study

Study design

Uncontrolled Clinical Trial

The Ethical clearance number is: IEC/Doc./03/10 dated 24.03.2012 (Institutional Ethics Committee, V.P.S.V

Ayurveda College, Kottakkal)

\section{Settings}

OPD \& IPD-VPSV Ayurveda College Hospital, Kottakkal, India

OPD \& IPD- Government Ayurveda Research Institute for Mental Diseases, Kottakkal, India

Duration of treatment: 5 weeks

Sample size: 20

\section{Diagnostic criteria}

ICD-10 diagnostic criteria for Mania without psychotic symptoms ${ }^{6}$

\section{Inclusion criteria}

- Both sexes

- Age limit-20-50 yrs

- No discrimination of religion and occupation

Exclusion Criteria

- Patients with organic mental disorders.

- Those who are under psychiatric medications.

- Those who are contraindicated to Nasya. 
- Those with major systemic disorders. Drug Study

Table 1: Ingredients of Sidharthakadi Yoga

\begin{tabular}{|c|c|}
\hline 1.Brassica juncea & 11.Emblica officinalis \\
\hline 2.Acorus calamus & 12.Clitoria ternatea \\
\hline 3.Ferula narthex & 13.Azadiracta indica \\
\hline 4.Callicarpa macrophylla & 14.Pongamia pinnata \\
\hline 5.Curcuma longa & 15.Albizia lebbeck \\
\hline 6.Coscinium fenestratum & 16.Cedrus deodara \\
\hline 7.Rubia cordifolia & 17.Zingiber officinale \\
\hline 8.Abrus precatorius & 18.Piper nigrum \\
\hline 9.Terminalia chebula & 19.Piper longum \\
\hline 10.Terminalia bellerica & 20.Bastamutra (Goat's urine) \\
\hline
\end{tabular}

\section{Preparation of Siddhartakadi Yoga}

The ingredients were collected and the medicines were prepared at Aryavaidyasala Kottakkal, which is a GMP certified pharmacy.

Sidharthakadi Gutika- For Nasya

The ingredients of Siddhartakadi Yoga were grinded with basthamutra for 20 days and made gutikas weighing $1 \mathrm{~g}$ each. At the time of Nasya this was grinded with water. Then it was filtered and used for nasya.

Sidharthakadi Tablet-For internal medication

The ingredients of Siddhartakadi Yoga was potentiated with basthamutra and made into tablet form (1g medicine). This was given internally.

\section{Modes of administration}

( $1^{\text {st }}$ seven days Nasya, then 30 days internal medication)

\section{Nasya-Kalka Nasya}

Dose-12 drops (6 drops in each nostril)

Time of administration-Morning (Between 8am \&10am)
Duration of treament-7 days

\section{The Procedure of Nasya}

Preparation of the nasyadravya- 1 Siddhartakadi Guțika is grinded in $2.5 \mathrm{ml}$ of boiled and cooled water and it was filtered and squeezed through cotton.

Poorvakarma- Abhyanga over the face with tilataila and bashpasveda was done with boiling water after covering the eyes with cotton.

Pradhanakarma- Patient was advised to lay down over the table. The nasyadravya was taken in a dropper and 6 drops each were dropped in each nostril. Then massage was done over the forehead, cheeks, neck, shoulders, palms and soles. The patient was advised to spit the phlegm to vessels placed near both sides of the head. Then the patient was advised to lay down for 2 minutes.

Paschatkarma- Kabala with warm water.

The procedure was repeated for 7 days.

Internal administration (In tablet form)

Dose- 6 tablets daily ( 3 tabs morning, 3 tablets evening)

Time of administration- 9am \& 9pm (after food)

Anupana-Warm water

Duration of treatment-1 month

Data Collection Procedure

The data was collected as per Case Record Form.

Severity of symptoms was rated with the help of Young Mania Rating Scale ${ }^{7}$.

Rating was done before Nasya, after 7 days of Nasya and after 30 days of internal medication.

Data Analysis Procedure

The Outcome data was measured and statistically analysed by the 'student paired t test'.

\section{OBSERVATION}

Table 2: Effect of Therapy on Individual symptoms
\begin{tabular}{|c|c|c|c|c|c|}
\hline Symptoms & BT & AT & $\%$ of relief & $\mathrm{P}$ value & \\
\hline Elevated mood & 2.6 & 1.45 & $44.23 \%$ & $\mathrm{P}<0.01$ & Significant \\
\hline Increased motor activity & 2.65 & 2.00 & $24.53 \%$ & $\mathrm{P}<0.01$ & Significant \\
\hline Hyper sexuality & 2.30 & 1.20 & $47.83 \%$ & $\mathrm{P}<0.001$ & Significant \\
\hline Decreased need for sleep & 2.70 & 1.90 & $29.63 \%$ & $\mathrm{P}<0.01$ & Significant \\
\hline Irritability & 2.45 & 1.35 & $55.10 \%$ & $\mathrm{P}<0.001$ & Significant \\
\hline Pressure of speech & 3.45 & 0.75 & $78.26 \%$ & $\mathrm{P}<0.001$ & Significant \\
\hline Language \& Thought Disorder & 2.75 & 2.30 & $16.36 \%$ & $\mathrm{P}<0.01$ & Significant \\
\hline Thought content & 2.70 & 1.90 & $29.63 \%$ & $\mathrm{P}<0.001$ & Significant \\
\hline Aggressive Behaviour & 2.30 & 1.00 & $56.52 \%$ & $\mathrm{P}<0.001$ & Significant \\
\hline Appearance & 2.15 & 1.85 & $13.95 \%$ & $\mathrm{P}<0.05$ & Significant \\
\hline Lack of Insight & 3.15 & 1.90 & $39.68 \%$ & $\mathrm{P}<0.001$ & Significant \\
\hline
\end{tabular}

\section{RESULT}

After the completion of the treatment with Sidharthakadi Yoga, it was seen that all the individual symptoms were reduced. The significant improvement was seen in the pressure of speech. The next symptoms improved were aggressiveness and irritability. These are the factors with which the relatives are the most concerned. They reported that there is no nuisance by the patient now. Hyper sexuality and elevated mood are observed to be reduced much. The elaborating on sexual matters in speech was reduced after treatment. Elevated mood came down to normal mood. The insight was improved from complete denial of the illness. The patients admitted that their activities were abnormal before the treatment.

\section{DISCUSSION}

\section{Probable mode of action}

Ayurvedic treatment is based on tridosha principle. But as far as ayurvedic psychiatry is concerned there is chance of mental disorders by causes other than tridoshas. There are some mental disorders which are different from doshaja unmada in nidana, poorvaroopa, lakshana, samprapti and upasaya. They are called bhootonmadas. They are the conditions which cannot be explained based on tridoshas. Even though mania seems to be paittika condition based on tridosha theory, in this study it was compared to grahas. Theekshnaprayoga was done on this basis.

Mania is a condition with elevated mood, increased energy and activities, decreased need for sleep, lack of social inhibitions and hyper sexuality etc which can be compared to Rakshasa graha. Teekshna nasya is contraindicated in calm grahas -Devagra, Rishigraha, 
Pitrugraha, Gandharvagraha ${ }^{8}$ so, Teekshna nasya is indicated in the remaining grahas-i.e. the grahas with aggressiveness like Rakshasagraha, Asuragraha etc. Siddhartakadi Yoga is indicated in Graha especially in asura grahas. This is very teekshna.

Siddhartakadi Yoga clears the srotas by which the vata is reduced.There are many medhya drugs -vacha, hingu, hareetaki, sankhapushpi and pippali. These may also be acting to stimulate prajna and correct the prajnaparadha (deviation from dhee, dhrti and smruti) ${ }^{9}$. The samprapti of bhootonmada starts with prajnaparadha ${ }^{10}$. Grahachikitsa will be complete only by correcting prajna.

The manasadosha which is predominant in mania is rajas. Wherever there is rajas there will be tamas also ${ }^{11}$. By teeksnaprayoga with medhya, drugs will help to decrease rajas and tamas and increase satwaguna by clearing the manovahasrotas.

The formulation was useful in decreasing all the humors. Vaata, pitta and kapha were cured by this formulation. We cannot predict the combined action of all the ingredients in a formulation.

\section{CONCLUSION}

From this study, we can conclude that the sidharthakadi yoga is effective in the management of mania without psychotic symptoms. The teekshnata of the drug do not aggravate the symptoms of mania. From this it can be said that, there is another principle other than tridoshas in mental disorders like mania. It is the concept of bhoothonmada. Theekshnaprayoga is indicated in grahas like rakshasa, asura and brahmarakshasa. These grahas are aggressive and violent. This principle was suitable to adopt here.

In bhootapratishedha, the oushadhachikitsa indicated are teekshna nasya, anjana etc and ghrtapaana. If the physician is able to differentiate doshaja unmada and bhootonmada clinically, he/she can select proper treatment. The nasya and anjana mentioned in bhootapratishedha can be done initially in bhootonmada. Bhootonmada is not caused by doshas so, nasya and anjana can be done as an emergency management without vamana and virechana or in doshaja unmada, if the symptoms are not completely cured by vamana, virechana etc, teekshna nasya, anjana can be done. Sidharthakadi nasya and intake worked in all the symptoms of mania without psychotic symptoms.

Statistically, the Null Hypothesis was rejected and alternate Hypothesis was accepted. i.e. Sidharthakadi Yoga has significant effect in the management of mania without psychotic symptoms.

\section{REFERENCES}

1. Vagbhata-Astangahrdaya with Sasilekha commentary of Indu, Chowkhamba Krishnadas Academy- Varanasi-2007, uttarasthana-6/10

2. Vagbhata-Astangahrdaya with Sasilekha commentary of Indu, Chowkhamba Krishnadas Academy- Varanasi-2007, uttarasthana-6/7

3. Vagbhata-Astangahrdaya with Sasilekha commentary of Indu, Chowkhamba Krishnadas Academy- Varanasi-2007, uttarasthana-4/26

4. Vagbhata-Astangahrdaya with Sasilekha commentary of Indu, Chowkhamba Krishnadas Academy- Varanasi-2007, uttarasthana-4/24

5. Vagbhata-Astangahrdaya with Sasilekha commentary of Indu, Chowkhamba Krishnadas Academy- Varanasi-2007, uttarasthana-5/10

6. World Health organization, The ICD-10 Classification of Mental and Behavioural Disorders, A.I.T.B.S Publishers and distributors, New Delhi., 2007

7. http://psychology-tools.com/young-mania-rating-scale

8. Vagbhata-Astangahrdaya with Sasilekha commentary of Indu, Chowkhamba Krishnadas Academy- Varanasi-2007, Uttarasthana-5/48

9. Agnivesa, Carakasamhita with the commentary of Cakrapanidatta(Chowkhambha Krishnadas academy-Varanasi) Sareerastana 1/1022006

10. Vagbhata-Astangahrdaya with uttarasthana-5/sasilekha commentary of Indu, Chowkhamba Krishnadas Academy- Varanasi-2007, Uttarasthana-4/3,4

11. Agnivesa, Carakasamhita with the commentary of Cakrapanidatta(Chowkhambha Krishnadas academy-Varanasi) Vimanastana 6/9 -2006

\section{Cite this article as:}

T.S. Manikandan, M. Jithesh. A study on the efficacy of Sidharthakadi yoga in the management of Mania without Psychotic symptoms-An uncontrolled clinical trial. Int. J. Res. Ayur. Pharm. 2012; 3(6):859-861 